Grossulariaceae (Currant Family)

Ribes oxyacanthoides L.; NORTHERN

GOOSEBERRY. Woods.

\section{Lamiaceae (Mint Family)}

Glechoma hederacea L.; CREEPING

CHARLIE. Roadside.

\section{Liliaceae (Lily Family)}

Disporum trachycarpum (S. Wats.) B. \& H.; FAIRYBELLS. Woods

Maianthemum canadense Desf. var. interius Fern.; TWO-LEAVED

SOLOMON'S-SEAL. Woods.

\section{Oleaceae (Olive Family)}

Fraxinus pennsylvanica Marsh.; GREEN ASH. Woods.

\section{Onagraceae (Evening-primrose}

\section{Family)}

Epilobium angustifolium L.;

FIREWEED. Bank.

\section{Poaceae (Grass Family)}

Bromus inermis Leyss.; SMOOTH BROME. Roadside.

\section{Ranunculaceae (Crowfoot Family)}

Thalictrum venulosum Trel.; VEINY MEADOW-RUE. Woods.
Rhamnaceae (Buckthorn Family)

Rhamnus alnifolia L'Her; ALDER-

LEAVED BUCKTHORN. Woods.

\section{Rosaceae (Rose Family)}

Amelanchier alnifolia Nutt.;

SASKATOON. Woods.

Rubus pubescens Raf.; DEWBERRY.

Woods.

Rosa woodsii Lindl.; WOOD'S ROSE.

Woods.

Rubus idaeus L.; CANADA

RASPBERRY. Woods.

Potentilla anserina L.; SILVERWEED.

Bank.

Salicaceae (Willow Family)

Populus balsamifera L.; BALSAM OR

BLACK POPLAR. Woods.

\section{Violaceae (Violet Family)}

Viola pubescens Ait. var. scabriuscula Schw.; SMOOTH YELLOW VIOLET.

Woods. (S1; THR)

1. Harms, Vern and Les Baker. 1998. A preliminary floral list for the Rendek Elm Forest Nature Sanctuary in east-central Saskatchewan. Blue Jay 56 (4): 213-215

\title{
FOUR INTRODUCED SPECIES NEW TO SASKATCHEWAN FROM THE 1990s
}

JOHN H. HUDSON, 103 Richmond Crescent, Saskatoon SK, S7K 1A9

The plant records reported here have nothing in common with one another except that they are all introductions two weeds pure and simple, one forage grass, and one garden escape. There is a theme behind this - people write of the plague of exotics already in our flora, but in this age of world-wide transport, more exotics keep arriving.

One of the mere weeds is Senecio viscosus L., Stinking Groundsel, 


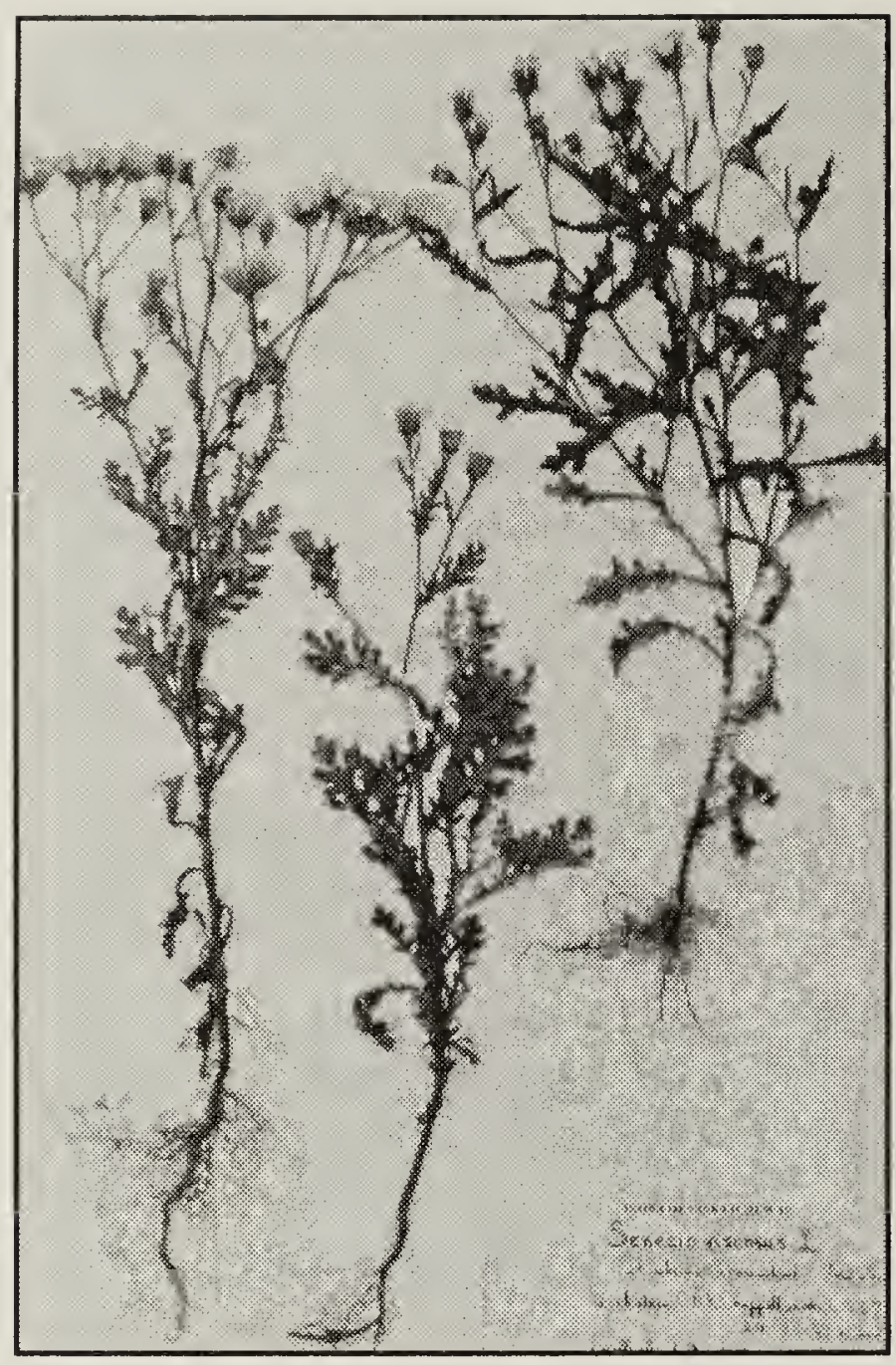

Stinking Groundsel, pressed specimen in $\mathrm{JHH}$ collection

A. Leighton

collected as \#5128 a on 2 September 1993 as a weed in the CNR chappell yards at Saskatoon on L.S.D.7 in 2436-VI W. $3^{\text {rd }} .^{\mathrm{b}}$ This European exotic has been reported from Winnipeg and from B.C. and eastern Canada by Boivin and by Scoggan. ${ }^{1,2}$ Closer to home, Krivda reports it from The Pas, Manitoba, also from railway gravels. ${ }^{3}$ Presumably, it arrived among us by rail.

Stinking Groundsel is much like the common, weedy Senecio vulgaris L., Common Groundsel, differing from the latter in its flower heads bearing rays 5 $\mathrm{mm}$ long and its leaves and stems having sticky pubescence. The glands of these hairs endow the plant with a smell of anaerobic sewage lagoons.

I checked in 1994 to see whether this plant was still present - it was - but since then my wanderings have not trended that way.

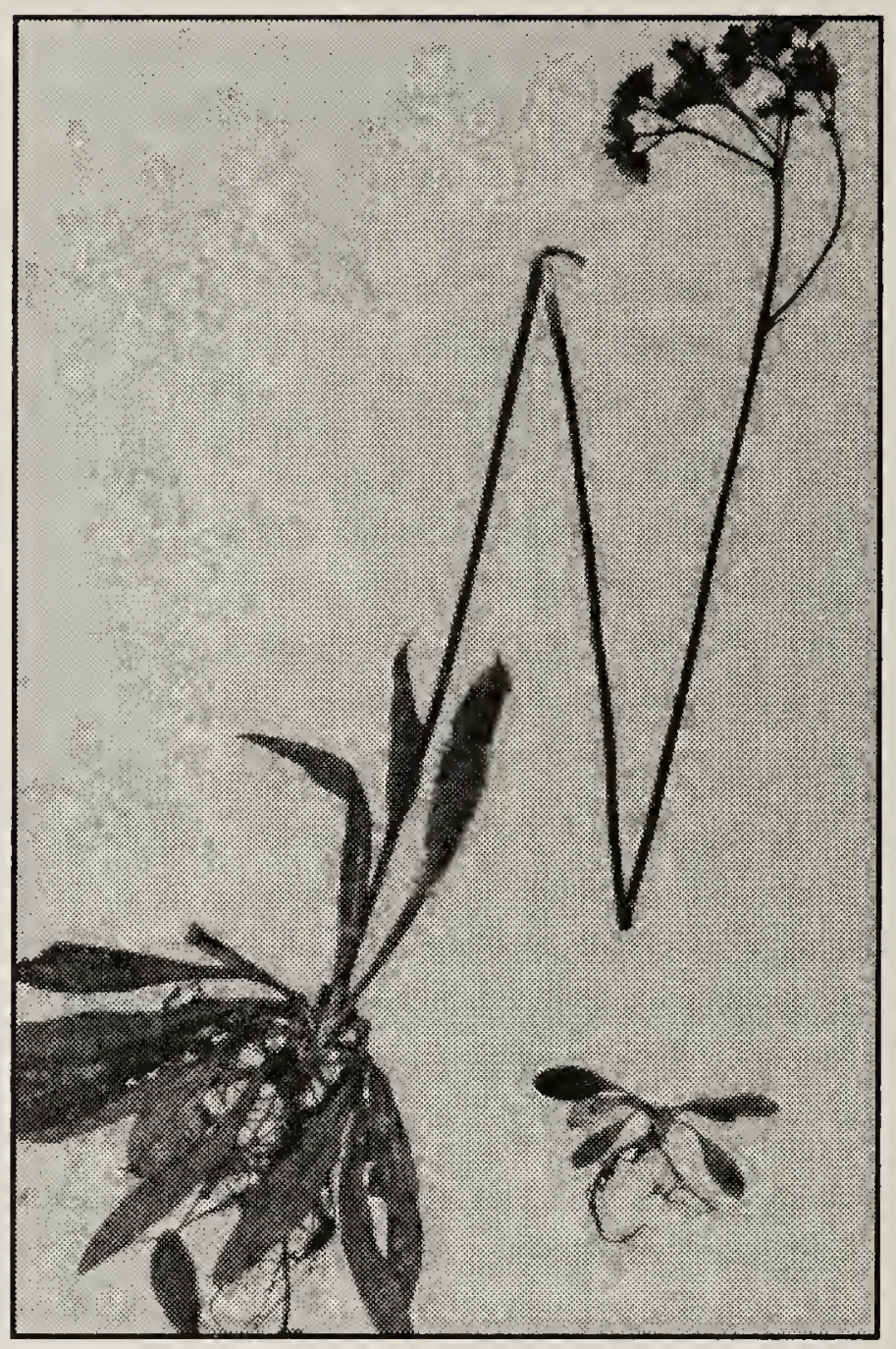

Orange Hawkweed, pressed specimen in $\mathrm{JHH}$ collection

A. Leighton

The other weed to report is Hieracium aurantiacum L., Orange Hawkweed or Devil's Paintbrush, collected at the junction of Highways 102 and 905, at lat. $56^{\circ} 15^{\prime} 50^{\prime \prime} \mathrm{N}$ and long. $103^{\circ} 33^{\prime} 15^{\prime \prime} \mathrm{W}$, 14 miles $(22.5 \mathrm{~km})$ west of Southend, Sask. Collection data are: "\#5267, 13 Sept. 1996, small borrow pit at highway junction, 15-30 flowering plants and lots of offset rosettes." ("Offset rosettes" are first year rosettes of leaves borne on above-ground runners from the base of the parent plant, as seen in many species of Pussy-toes (Antennaria spp). Eventually these take root.)

This Hawkweed, like the legion of introduced hawkweeds of eastern Canada, differs from our native Hieracium umbellatum L., Canada Hawkweed, in its conspicuously spreading pubescence and its leaves all or mostly in a basal rosette. However, its reddish-orange ray- 
flowers unmistakably set it apart from all these other hawkweeds, and indeed, from all other Chicory tribe composites that one is likely to see in Saskatchewan.

The colony was still present in the summers of 1998 and 1999, but did not seem to have spread. Plainly, it came in by road transport. One would guess from its successful invasion of humid eastern Canada, that it must need humid conditions throughout the summer such as are found in the Prairie Provinces only far north in the Boreal Forest.

Another far northern discovery is Alopecurus pratensis L., Meadow Foxtail, collected as \#5149 on 25 July 1994 at a landing place on the west bank of Waddy River at its mouth on Brabant Lake, $\left(56^{\circ} 07^{\prime} \mathrm{N}\right.$ and $\left.103^{\circ} 44^{\prime} \mathrm{W}\right)$. This good sized grass, 5-10 dm high, looks like the cultivated Timothy except that

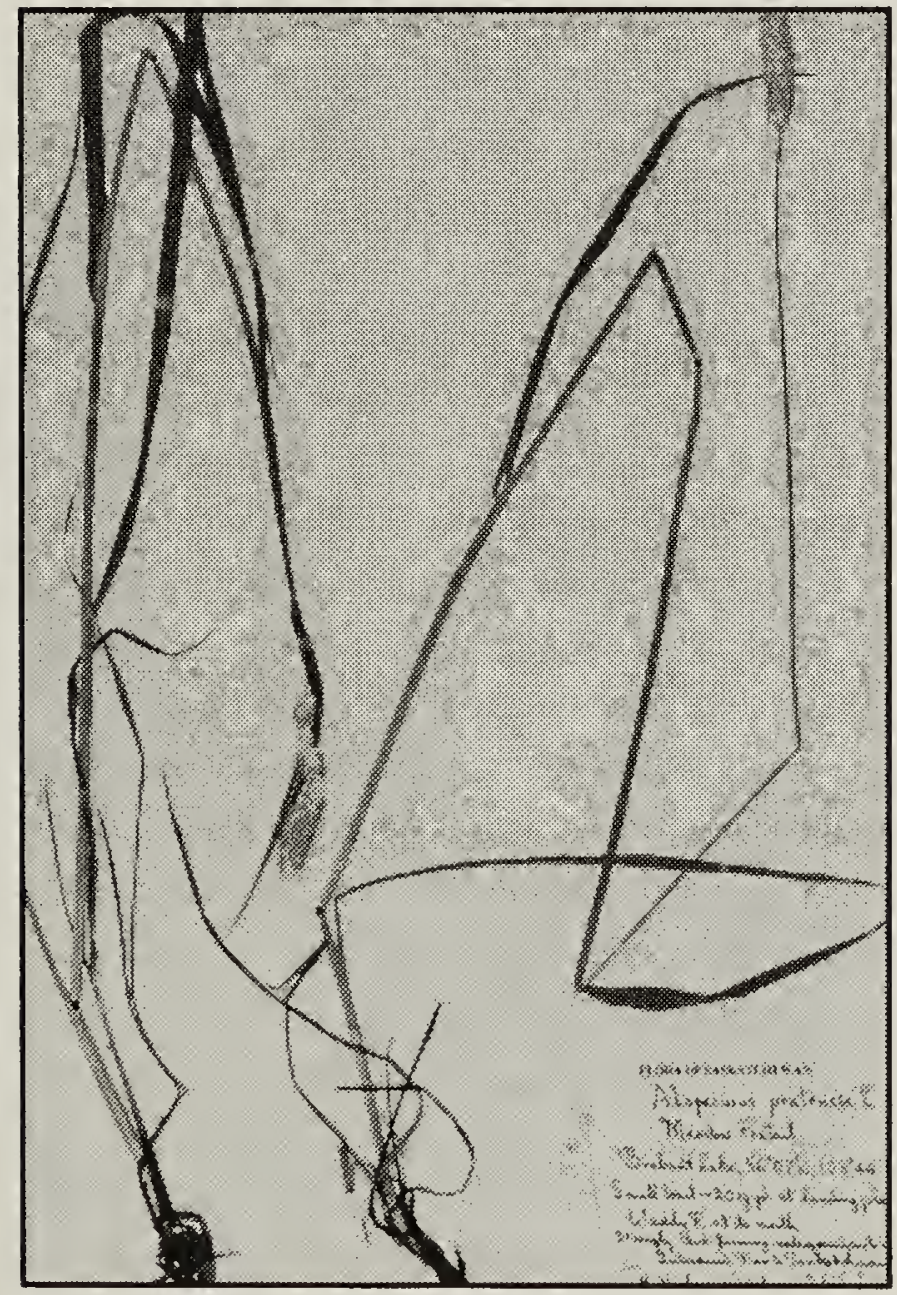

Meadow Foxtail, pressed specimen in JHH collection prominent awns project from the cigarshaped spike-like panicles, and that it has rhizomes. Indeed, it formed so stiff a sod that major effort was needed to collect the underground parts. There was a patch of about 20 square yards at the collection site, and I saw a few plants 50 or 100 yards up river at another landing place. These landing places are on the south side of Highway 102. Just north of this road the river passes over a roaring falls coming out of Waddy Lake.

Floras state of Meadow Foxtail that it is a common meadow grass in Europe, also common in the introduced state in eastern North America and the West Coast. In the Prairie Provinces, Boivin gives four collection localities, two in eastern Manitoba and two in western Alberta. ${ }^{1}$ Presumably, like Orange Hawkweed, only far northern Saskatchewan offers moist enough conditions for this grass to survive the summer.

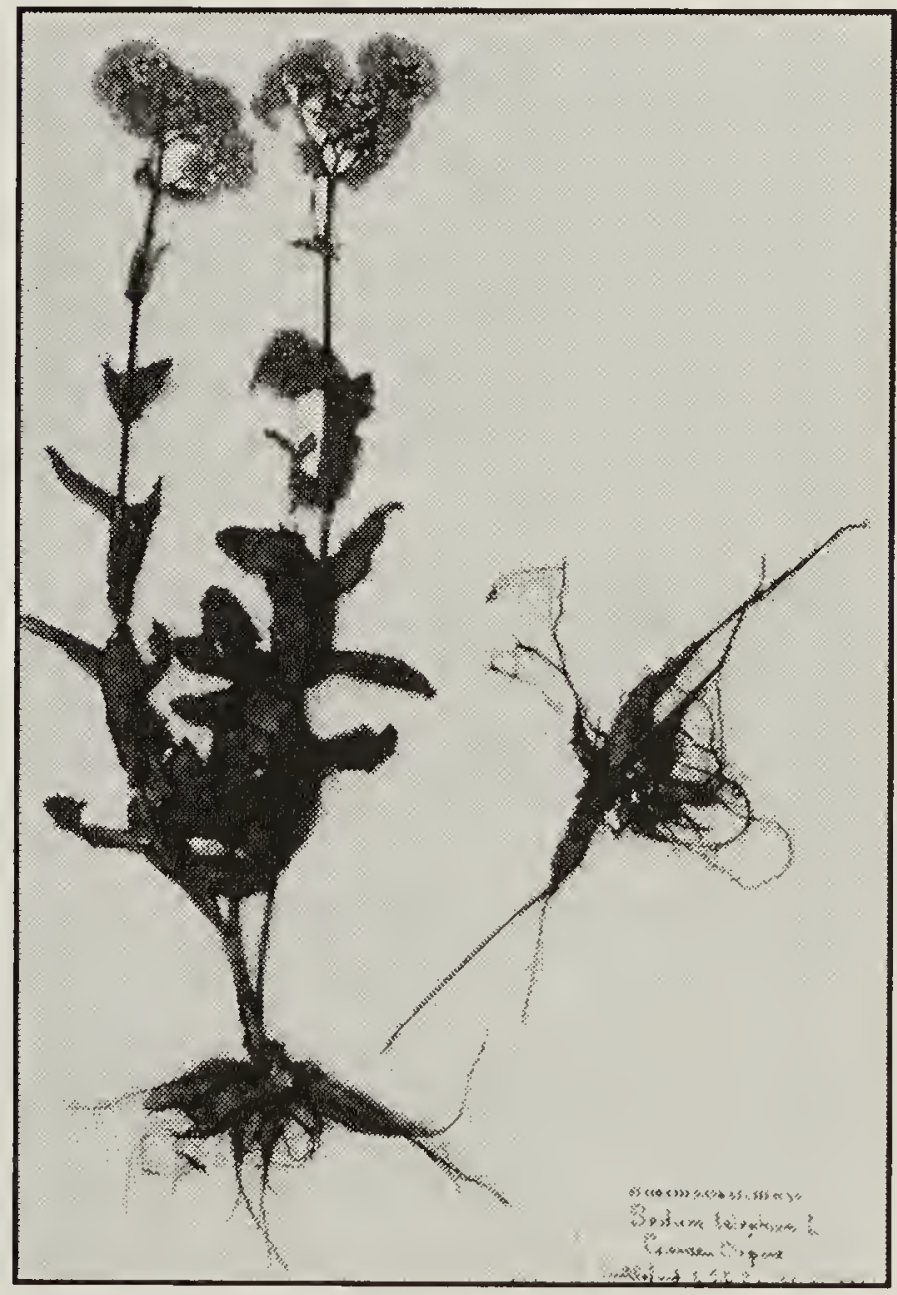

Garden Orpine, pressed specimen in JHH collection

A. Leighton 
Finding this grass at landing places may just be because in the northern coniferous forest only a landing place has the trees and shrubs hacked down and the moss and lichen trodden down, without other disturbance of the soil surface, so that a sward-forming grass can grow and persist.

The garden escape is Sedum telephium L., Garden Orpine, collected as \#5172 from the road ditches of Highway 26 in sandy soil south of Spruce Lake village on L.S.D. 2 in $33-$ $51-X X 1$ W. $3^{\text {rd }}$ on 26 August 1994. This stonecrop must have escaped from cultivation but it was doing nicely - there were stands of it in the highway ditch for a couple of miles north of the collection location.

This Garden Orpine has fleshy, broadly oblong leaves $3-6 \mathrm{~cm}$ long by $1.5-2.5 \mathrm{~cm}$ wide, strung out alternately along the $3-5 \mathrm{dm}$ high stem, which is topped by dense hemispherical bunches of small 5-petalled flowers of a pale yellow hue. Some floras, as Gleason, claim the petals to be red-purple; others, as Fernald, state them to be greenish yellow or creamy, as were those of this collection. ${ }^{4,5}$ For a garden escape, the flower color in the field will depend on what cultivar escaped in that particular area.

Boivin and Scoggan cite a collection of Garden Orpine from The Pas, Manitoba, along with the usual reports from B.C. and eastern Canada. ${ }^{1,2}$

Duplicates of these collections have been sent to the W. P. Fraser Herbarium of the University of Saskatchewan, to that of the National Museum of Canada and to that of the University of Regina.
${ }^{a}$ All collection numbers are those of the author.

${ }^{b}$ An L.S.D. is a legal subdivision of a section, being one-sixteenth of a section or 40 acres in size. L.S.Ds are numbered in the same fashion as sections within a township. Section, township and range (in Roman numerals) designations follow the L.S.D. number and W. $3^{\text {rd }}$ means west of the one hundred and third meridian.

1. Boivin, B. 1967-1981. Flora of the Prairie Provinces, in 5 parts. Provancheria, Memoires de l'Herbier Louis-Marie, Universite Laval, Quebec City.

2. Scoggan, H. J. 1978-1981. Flora of Canada. National Museums of Canada, Ottawa.

3. Krivda, W. 1987. The Sticky Groundsel at The Pas, Manitoba. Blue Jay 45(3) : 145.

4. Gleason, H. A. 1952. The New Britton \& Brown lllustrated Flora of the Northeastern United States and Adjacent Canada. The New York Botanical Garden, N.Y.

5. Fernald, M. L. 1950. Gray's Manual of Botany, 8th Edition. American Book Company, N.Y. 